\title{
Heavy Metal Determination in the Bottom Solid Waste Ash Produced from Sabah and Shuaiba Hospital Incinerators in Kuwait
}

\author{
Saleh Al-Muzaini \\ Earth Sciences and Environment Department, Kuwait University, Safat 23942, Kuwait
}

\begin{abstract}
In Kuwait, there is growing concern over the disposal of wastes produced by hospitals since hospital wastes contain hazardous and infected wastes. All hospitals in Kuwait have adopted incineration as an alternative method to dispose of their wastes. Due to inefficient combustion of hospital incinerators, the Kuwaiti government decided to shut down all hospital incinerators, while the Sabah Incinerator (SAHI) and Shuaiba Incinerator (SUHI) were kept running. This study was initiated to focus on the determination of heavy metals in the bottom ashes produced by the SAHI and SUHI incinerators. Bottom ash was collected over a period of one year and heavy metals were determined. They were shown variation in their concentrations due to the initial waste composition and the operational procedures of the hospital incinerators.
\end{abstract}

Key words: Hazard, hospital waste, incineration, toxic metals.

\section{Introduction}

In Kuwait, there is a major concern over the increasing amount of hospital wastes as shown in Fig. 1. The amount of hospital wastes generated have doubled in the past 40 years to reach $5 \mathrm{~kg}$ to $10 \mathrm{~kg}$ per patient, which corresponds to a total of $6 \times 10^{3}$ tons per year of hazardous hospital solid wastes. The expectation indicates that this figure will increase in the future due to the single disposable items used per patient [1].

Ninety-five percent of current hospital wastes were incinerated in nearly 25 facilities. However, inefficient combustion of hospital incinerators leads hospital incinerators to generate toxic emissions during their daily operations. As a result of epidemiological studies conducted by health authorities, it was revealed that there is a correlation between the proximity of a residence to a hospital incinerator and the incidence of various types of cancer. Thus, the health authorities decided to shut down hospital incinerators and retained

Corresponding author: Saleh Al-Muzaini, Ph.D., main research field: environment engineering. the operation of the Sabah Hospital Incinerators (SAHI), which was modernized later on. At the same time, a new incinerator was installed at Shuiaba area called Shuaiba Hospital Incinerator (SUHI). Even though incinerations are good means to reduce the volume of hospital wastes and eliminating infectious components, the subject of hospital incineration is still under public debate. Recent studies showed that the impact of carcinogenic emissions from new hospital incinerators on human health was to be much low [2]. Comprehensive studies have been carried out on the impact of air pollutants in fly ash, while some general information is available from recent published studies on the determination of heavy metals in the bottom ash of hospital incinerators, which are yet to be understood. A preliminary study was conducted on the nature of bottom ash from hospital incinerators in Kuwait in 2001. The results revealed that bottom ash produced by hospital incinerators contained high levels of heavy metals such as $\mathrm{Zn}, \mathrm{Fe}, \mathrm{Pb}, \mathrm{Cr}, \mathrm{Cu}, \mathrm{Mn}$, $\mathrm{Ni}$ and $\mathrm{Cd}$. The study suggested that further study should be conducted to understand the differences in the levels of heavy metals [3]. Lo, H. M., and Liao, 


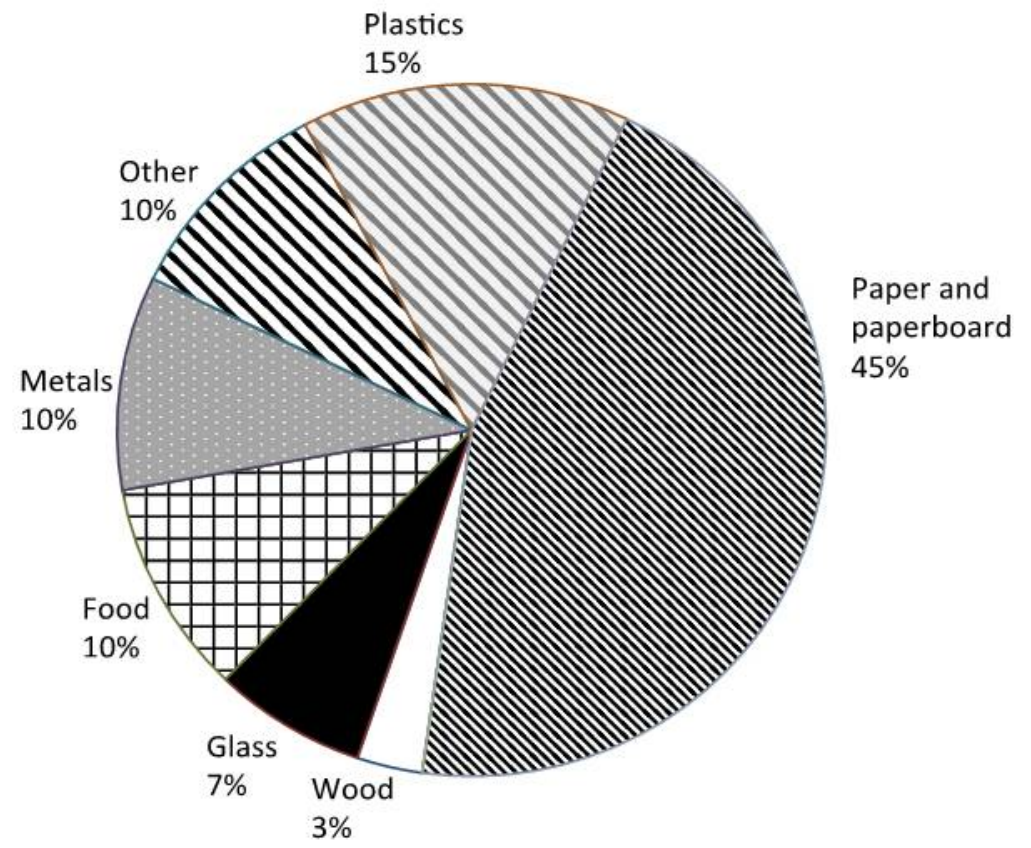

Fig. 1 Average hospital composition waste [33].

Y. L. [4] showed that incinerator bottom ash can create a significant risk to the environment. Recently, the European Union Council Declared that, hospital bottom ash as a dangerous waste material [5]. Unsafe disposal of hospital waste ash in a landfill can cause contamination to the soil and groundwater due to leaching of heavy metals [6]. For this reason, hospital waste ash requires special attention [7] during its disposal. Alba, N., et al. [8] reported that six hospital medical waste incinerator samples in northern Spain were collected and analyzed. Results showed high concentrations of chromium in hospital waste ash. However, Zhao, L., et al. [9] studied the chemical properties of heavy metals in hospital wastes incinerator ashes in China. They reported that heavy metals, such as $\mathrm{Ca}, \mathrm{Cr}$ and $\mathrm{Na}$ were found in various quantities, where $\mathrm{Cr}$ had the highest concentration among other heavy metals. Kougemitrou, I., et al. [10] studied bottom ash samples from hospital waste incinerators in Athens, Greece. The results of their research showed that hospital waste ash contained a high content of heavy metals such as $\mathrm{Cu}$ and $\mathrm{Cr}$. Zhao, L., et al. [11] studied hospital waste incinerator ash due to the outbreak of severe acute respiratory syndromes in China. The analyses showed that hospital bottom ashes contained a larger amount of heavy metals such as $\mathrm{Ba}, \mathrm{Cu}, \mathrm{Cr}, \mathrm{Mn}, \mathrm{Ni}, \mathrm{Pb}, \mathrm{Sn}, \mathrm{Ti}$ and $\mathrm{Zn}$. Heavy metals, such as $\mathrm{Ba}, \mathrm{Cr}$, Ni and $\mathrm{Sn}$, were present in the residual fraction, while $\mathrm{Mn}, \mathrm{Pb}$ and $\mathrm{Zn}$ were present in the Fe-Mn oxides fraction and $\mathrm{Cu}$ was present in the organic matter fraction. Zakaria, M., et al. [12] evaluated hospital waste incinerator performances based on their physical and chemical characteristics of bottom ashes. They concluded that incineration processes can easily destroy organic compounds and some heavy metals found in the hospital wastes. Furthermore, Levasseur, B., et al. [13] reported the hospital incinerators could produce large quantities of bottom ashes depend is on the amount of hospital wastes. Astar, M. [14] reported that incineration provides the ultimate means of disposal for toxic compounds. Tessitors, J., and Frankle, C. [15] pointed out that many hospital authorities decided to dispose of all hospital wastes through incineration for the following reasons: (1) landfill authorities are unwilling to accept any hospital wastes, and (2) liability consideration due to possible transmission of diseases such as AIDS and viral diseases. Doyle, B.W., 
et al. [16] and Timothy A., et al. [17] stated that pollutants in the bottom ashes from hospital waste incinerators may pose hazards to the environment if they are not properly disposed of. Rich, C., and Cherry, K. [18] pointed out that it is important to have a clear procedure to dispose of hospital wastes, as otherwise, these is a risk of severe acute respiratory diseases spreading later on. While Shen, T. [19] highlighted that the public are always concerned about hospital wastes, the potential risk always existed. Over $80 \%$ of many main elements, such as $\mathrm{Fe}, \mathrm{P}, \mathrm{Al}, \mathrm{Sr}, \mathrm{Ca}$ and some of the toxic elements, such as $\mathrm{Cr}, \mathrm{Co}, \mathrm{Mg}$, $\mathrm{Ni}$, Mo can remain in the bottom ash after incineration [20]. Also, $90 \%$ of $\mathrm{Cd}$ and $88 \%$ of $\mathrm{Sb}$ can be volatilized but they also remain in the bottom ash [20]. Based on recent research, low volatility heavy metals, such $\mathrm{Ni}, \mathrm{Cr}, \mathrm{Cu}$ and $\mathrm{Zn}$ always remain in the bottom ash [21]. The aim of this work was to identify heavy metals and their levels in hospital bottom ash and to compare the results of this study with published results. For this study, bottom ash samples were collected and analyzed over a period of one year.

\section{Materials and Methods}

\subsection{Hospital Incinerator}

This study was carried out in two hospital incinerators-SAHI and SUHI. They are located in urban areas. The nature of the incinerated waste is hospital waste and hospitals regularly incinerate without any preliminary sorting. SAHI was built in 1980 but since 2002 major technical modifications were made to update the current standards. SUHI, the second incinerator was built in 2010 and is located in the south of Kuwait city. Both incinerators are equipped with two combustion chambers with design capacities between $350 \mathrm{~kg} / \mathrm{h}$ and $650 \mathrm{~kg} / \mathrm{h}$ of hospital wastes. They are fitted with efficient electrostatic precipitators and liquid lime scrubbers. The combustion chamber temperature goes up to $1,500{ }^{\circ} \mathrm{C}$. The decontaminated exhaust is released into the atmosphere by a $50 \mathrm{~m}$ high chimney. Bottom ash residues are transported by vibrating conveyors and stored in a bunker. All ash residues are subsequently transported to trucks for final disposal in a landfill.

\subsection{Bottom Ash Sampling and Analysis}

The bottom ash samples were collected from two incinerators. All samples were taken between January and December 2013. The bottom ash samples were collected at the end of operation day. A total number of 96 samples were collected in a period of one year from the combustion chamber. The samples were kept in a closed non-contaminating plastic bag. Each sample was about $1 \mathrm{~kg}$ to $2 \mathrm{~kg}$. After all of the samples were collected, they were transported to the laboratory where they were analyzed. In the laboratory, each ash sample was crushed in a porcelain mortar and pestle, passed through a \#40-mesh sieve, and stored in glass bottles. All ash samples were dried in the oven at $105^{\circ} \mathrm{C}$ for 3 hour to remove any humidity. Approximately 1 $\mathrm{gm}+2$ gm of dry ash sample was placed in a digestion tube and then $15 \mathrm{~mL}$ of $\mathrm{HNO}_{3}(100 \%)$ was added and mixed thoroughly for 1 hour at $70{ }^{\circ} \mathrm{C}$. The sample was cooled to room temperature before filtration. After filtration, $50 \mathrm{~mL}$ of the sample was collected and sent directly for analyses. The Inductively Coupled Plasma-Optical Emission Spectrometry (ICP-OES). Varian SPS3 analysis [22] was used for the analysis of heavy metals such as $\mathrm{Cd}, \mathrm{Co}, \mathrm{Cr}, \mathrm{Fe}$, $\mathrm{Ni}, \mathrm{Mn}, \mathrm{Mo}, \mathrm{Pb}, \mathrm{Se}, \mathrm{Sn}, \mathrm{Sr}, \mathrm{V}$ and $\mathrm{Zn}$. The ICP-OES instrument was already calibrated using reference standards and suitable blanks in order to produce high quality reading. Sampling and analysis were performed according to the Standard Methods [23].

\section{Results and Discussion}

\subsection{Chemical Characteristics of Bottom Ash}

The bottom ash samples were investigated for heavy metal concentration $(\mathrm{Cd}, \mathrm{Co}, \mathrm{Cr}, \mathrm{Cu}, \mathrm{Fe}, \mathrm{Mn}$, $\mathrm{Mo}, \mathrm{Ni}, \mathrm{Pb}, \mathrm{Se}, \mathrm{Sn}, \mathrm{Sr}, \mathrm{V}$ and $\mathrm{Zn}$ ). Table 1 shows the concentrations of heavy metals in the bottom ash of SAHI. 
Table 1 Concentration of heavy metals in bottom ash SAHI.

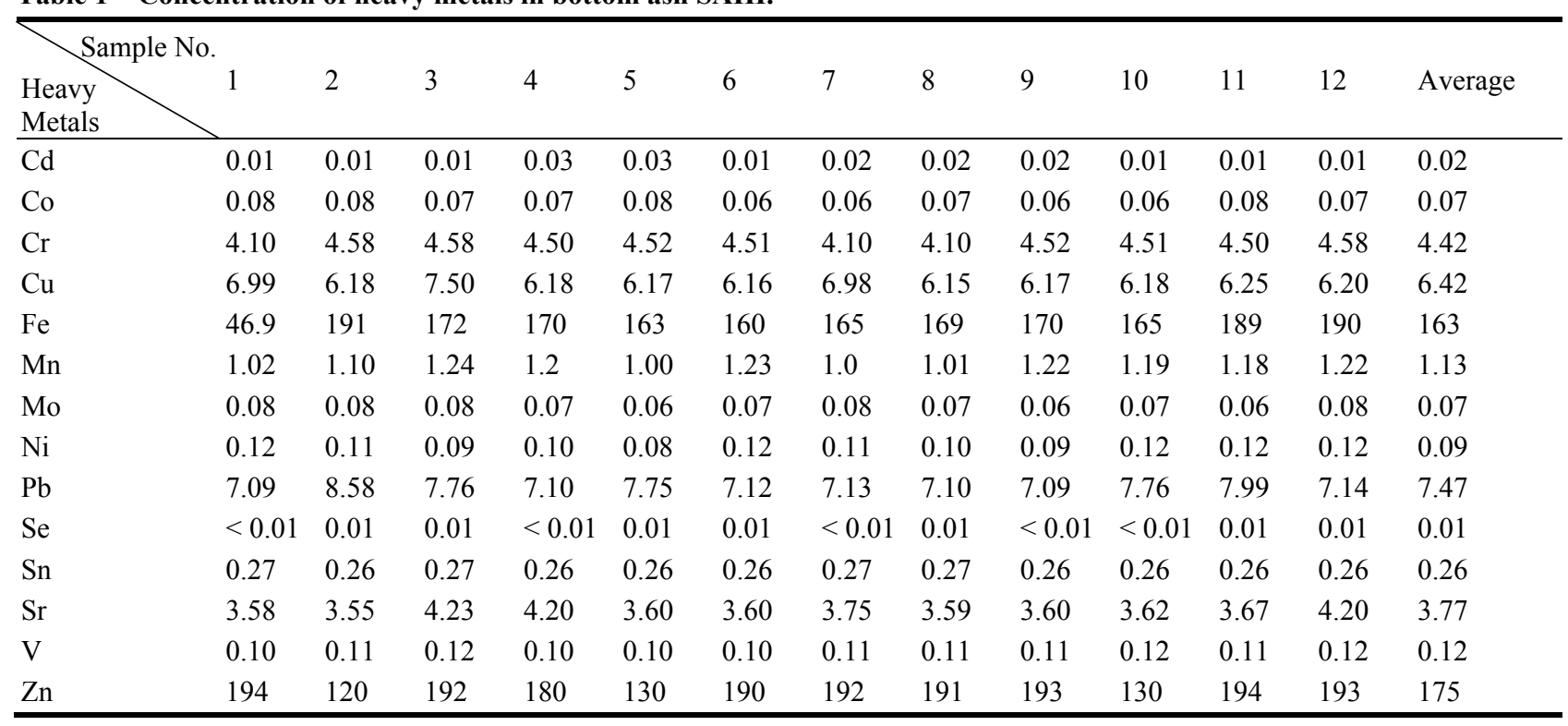

* All reading in $\mathrm{mg} / \mathrm{L}$.

The concentration of $\mathrm{Cd}$ varied from $0.01 \mathrm{mg} / \mathrm{L}$ to $0.03 \mathrm{mg} / \mathrm{L}$ with an average of $0.02 \mathrm{mg} / \mathrm{L}$, while Co concentration ranged from $0.06 \mathrm{mg} / \mathrm{L}$ to $0.08 \mathrm{mg} / \mathrm{L}$ with an average of $0.07 \mathrm{mg} / \mathrm{L}$. However, concentration of $\mathrm{Cr}$ ranged from $4.10 \mathrm{mg} / \mathrm{L}$ to $4.58 \mathrm{mg} / \mathrm{L}$ with an average of $4.42 \mathrm{mg} / \mathrm{L}$. The concentration of $\mathrm{Cu}$ ranged from $6.18 \mathrm{mg} / \mathrm{L}$ to $7.5 \mathrm{mg} / \mathrm{L}$ with an average of 6.42 $\mathrm{mg} / \mathrm{L}$, but $\mathrm{Fe}$ concentration ranged from $46.9 \mathrm{mg} / \mathrm{L}$ to $191 \mathrm{mg} / \mathrm{L}$ with an average of $163 \mathrm{mg} / \mathrm{L}$. The concentration of $\mathrm{Mn}$ varied from $10 \mathrm{mg} / \mathrm{L}$ to 1.24 $\mathrm{mg} / \mathrm{L}$ with an average of $1.13 \mathrm{mg} / \mathrm{L}$, and $\mathrm{Mo}$ concentration ranged from $0.06 \mathrm{mg} / \mathrm{L}$ to $0.08 \mathrm{mg} / \mathrm{L}$ with an average of $0.07 \mathrm{mg} / \mathrm{L}$. The concentration of $\mathrm{Ni}$ ranged from $0.08 \mathrm{mg} / \mathrm{L}$ to $0.12 \mathrm{mg} / \mathrm{L}$ with an average of $0.09 \mathrm{mg} / \mathrm{L}$. $\mathrm{Pb}$ concentrations ranged from 7.08 $\mathrm{mg} / \mathrm{L}$ to $8.58 \mathrm{mg} / \mathrm{L}$ with an average of $7.47 \mathrm{mg} / \mathrm{L}$; however, Se concentrations ranged from $<0.1 \mathrm{mg} / \mathrm{L}$ to $0.1 \mathrm{mg} / \mathrm{L}$ with an average of $0.1 \mathrm{mg} / \mathrm{L}$. Sn concentration varied from $0.26 \mathrm{mg} / \mathrm{L}$ to $0.27 \mathrm{mg} / \mathrm{L}$ with an average of $0.26 \mathrm{mg} / \mathrm{L}$. Sr, V and $\mathrm{Zn}$ concentrations ranged from $3.58 \mathrm{mg} / \mathrm{L}$ to $4.30 \mathrm{mg} / \mathrm{L}, 0.10 \mathrm{mg} / \mathrm{L}$ to $0.11 \mathrm{mg} / \mathrm{L}$, and $120 \mathrm{mg} / \mathrm{L}$ to $194 \mathrm{mg} / \mathrm{L}$, respectively, while their average concentrations were $3.77 \mathrm{mg} / \mathrm{L}, 0.12 \mathrm{mg} / \mathrm{L}$ and $175 \mathrm{mg} / \mathrm{L}$, respectively. The levels of heavy metals in bottom ash of the SAHI had an abundance of $\mathrm{Zn}>\mathrm{Fe}>\mathrm{Pb}>\mathrm{Cu}>\mathrm{Cr}>\mathrm{Sr}>\mathrm{Mn}>\mathrm{Sn}>\mathrm{V}>\mathrm{Ni}>$ $\mathrm{Mo}>\mathrm{Co}>\mathrm{Cd}>\mathrm{Se}$ in each sample. Table 2 shows the ash samples from SUHI.

$\mathrm{Cd}$ concentrations ranged from $0.01 \mathrm{mg} / \mathrm{L}$ to 0.02 $\mathrm{mg} / \mathrm{L}$ with an average of $0.02 \mathrm{mg} / \mathrm{L}$; however, Co concentrations ranged from $<0.01 \mathrm{mg} / \mathrm{L}$ to $0.03 \mathrm{mg} / \mathrm{L}$ with an average of $0.01 \mathrm{mg} / \mathrm{L}$. Cr concentrations ranged from $0.91 \mathrm{mg} / \mathrm{L}$ to $1.07 \mathrm{mg} / \mathrm{L}$ with an average of $0.94 \mathrm{mg} / \mathrm{L} . \mathrm{Cu}$ concentrations varied from 15.6 $\mathrm{mg} / \mathrm{L}$ to $79.7 \mathrm{mg} / \mathrm{L}$ with an average of $52.3 \mathrm{mg} / \mathrm{L}$; however, Fe concentrations ranged from $1.72 \mathrm{mg} / \mathrm{L}$ to $227 \mathrm{mg} / \mathrm{L}$ with an average of $197 \mathrm{mg} / \mathrm{L} . \mathrm{Mn}$ concentrations ranged from $2.10 \mathrm{mg} / \mathrm{L}$ to $3.44 \mathrm{mg} / \mathrm{L}$ with an average of $2.65 \mathrm{mg} / \mathrm{L}$, but Mo concentrations ranged from $0.01 \mathrm{mg} / \mathrm{L}$ to $0.05 \mathrm{mg} / \mathrm{L}$ with an average of $0.02 \mathrm{mg} / \mathrm{L}$. Ni concentrations varied from $0.5 \mathrm{mg} / \mathrm{L}$ to $0.76 \mathrm{mg} / \mathrm{L}$ with an average of $0.63 \mathrm{mg} / \mathrm{L}$, but $\mathrm{Pb}$ concentrations ranged from $27 \mathrm{mg} / \mathrm{L}$ to $35.3 \mathrm{mg} / \mathrm{L}$ with an average of $30.83 \mathrm{mg} / \mathrm{L}$. Se concentrations ranged from $<0.01 \mathrm{mg} / \mathrm{L}$ to $0.01 \mathrm{mg} / \mathrm{L}$ with an average of $0.01 \mathrm{mg} / \mathrm{L}$, but $\mathrm{Sn}$ concentrations varied from $0.60 \mathrm{mg} / \mathrm{L}$ to $0.72 \mathrm{mg} / \mathrm{L}$ with an average of 0.67 $\mathrm{mg} / \mathrm{L}$. Sr concentrations ranged from $2.17 \mathrm{mg} / \mathrm{L}$ to $3.20 \mathrm{mg} / \mathrm{L}$ with an average of $2.75 \mathrm{mg} / \mathrm{L}$, but $\mathrm{V}$ concentrations ranged from $0.06 \mathrm{mg} / \mathrm{L}$ to $0.09 \mathrm{mg} / \mathrm{L}$ 
Table 2 Concentration of heavy metals in bottom ash SUHI.

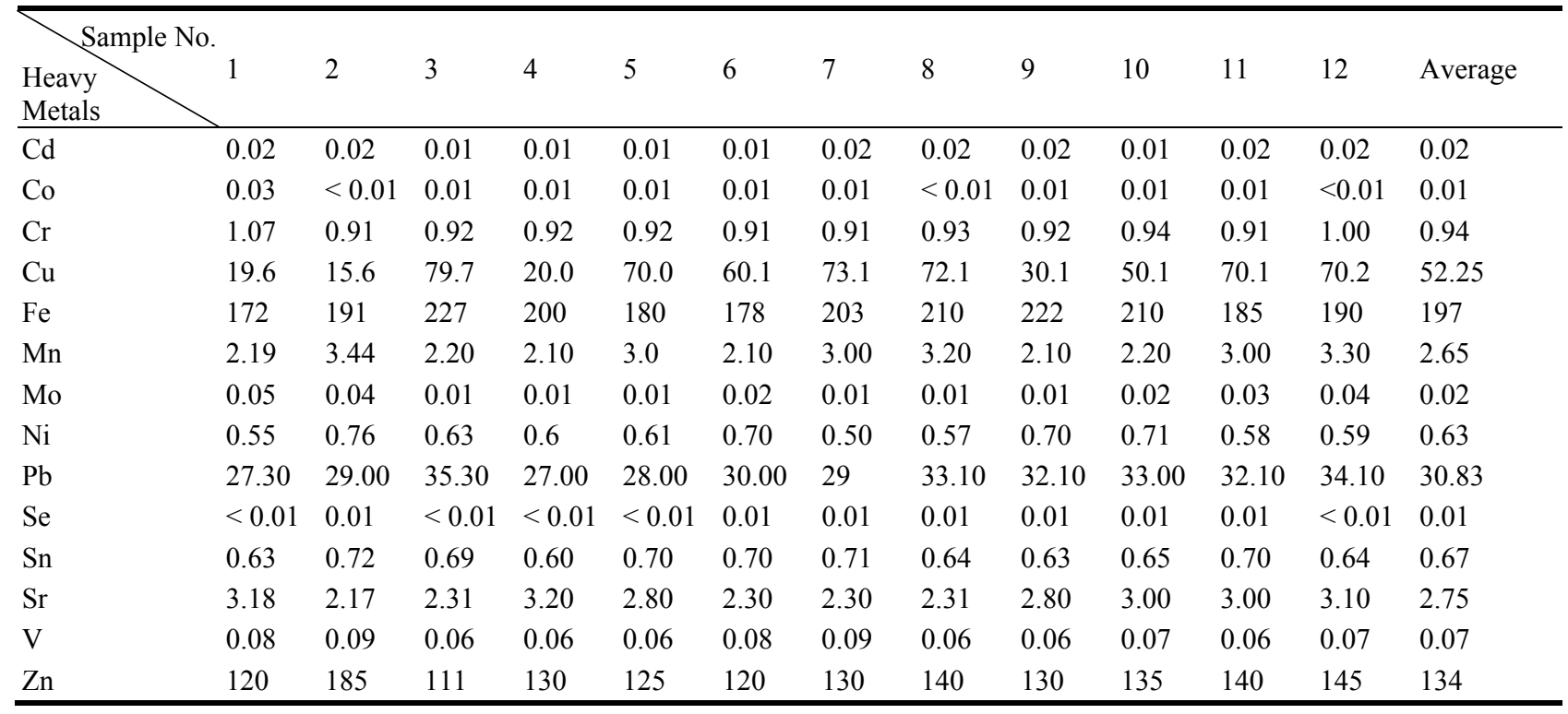

* All reading in $\mathrm{mg} / \mathrm{L}$.

with an average of $0.07 \mathrm{mg} / \mathrm{L}$. $\mathrm{Zn}$ concentrations ranged from $111 \mathrm{mg} / \mathrm{L}$ to $185 \mathrm{mg} / \mathrm{L}$ with an average of $134 \mathrm{mg} / \mathrm{L}$. The levels of heavy metals in the bottom ash of SUHI had an abundance of $\mathrm{Fe}>\mathrm{Zn}>\mathrm{Cu}>\mathrm{Pb}>$ $\mathrm{Sr}>\mathrm{Mn}>\mathrm{Cr}>\mathrm{Sn}>\mathrm{Ni}>\mathrm{V}>\mathrm{Mo}>\mathrm{Cd}>\mathrm{Co}>\mathrm{Se}$. In general, the levels of heavy metals in the bottom ash revealed a wide variation in the concentration of heavy metals due to the hospital wastes' contents.

This also means that incinerators were found to be inadequate in eliminating all of the metal contents. Furthermore, it appeared that the quantities of heavy metals in the hospital wastes may be high and cannot be eliminated easily by incineration. The concentration of Fe was the highest compared to other heavy metals, as shown in Fig 2. Also, metals, such as $\mathrm{Zn}, \mathrm{Cu}$ and $\mathrm{Pb}$, have high concentrations and can be compared to other elements. The variation in the concentration of heavy metals was probably due to two factors. The first factor was the variation in the hospital waste's composition, while the second factor was the improper operation of the two incinerators [24]. These levels were not unexpected since hospital wastes normally contain about $20 \%$ nonorganic materials and, occasionally, the levels increase as high as 30\% [24]. Results show that some of the toxic elements $(\mathrm{Cr}, \mathrm{Co}$,
$\mathrm{Mg}$, Ni and Mo) always remained in the bottom ash due to their properties of metals $[20,21]$. Table 1 shows that SAHI had the highest contents of $\mathrm{Zn}, \mathrm{Fe}$, $\mathrm{Pb}, \mathrm{Cu}, \mathrm{Cr}$, while $\mathrm{Zn}$ and $\mathrm{Fe}$ had the highest concentrations, while $\mathrm{Cd}$ and $\mathrm{Se}$ had the lowest concentrations. Table 2 shows that the concentrations of $\mathrm{Fe}, \mathrm{Zn}, \mathrm{Cu}, \mathrm{Pb}, \mathrm{Sr}$ and $\mathrm{Mn}$ were the highest among other metals, while Se, Co, Cd, Mo had the lowest concentrations. Presence of $\mathrm{Fe}$ and $\mathrm{Zn}$ in the bottom ashes of two incinerators may due to the presence of cans, bottle capsules, pigments, and plastic materials $[3,25]$. The results revealed that in comparing the total waste volume of two hospitals in the combustion chamber with the final ash residual collected after incineration process. Results indicated that the most of the waste loaded was burned properly and volume reduction has been achieved in all runs. The result also showed that the ashes collected from incineration process contained high concentrations of $\mathrm{Fe}, \mathrm{Zn}, \mathrm{Cu}$ and $\mathrm{Pb}$. This is due to the fact that their small particles sizes were present and increased their availability surfaces to expose more to the adsorption process. The results revealed that the highest concentration of $\mathrm{Fe}$ in the ash might have been due to its highest melting point $\left(1,493{ }^{\circ} \mathrm{C}\right)$, which makes it available in a larger 


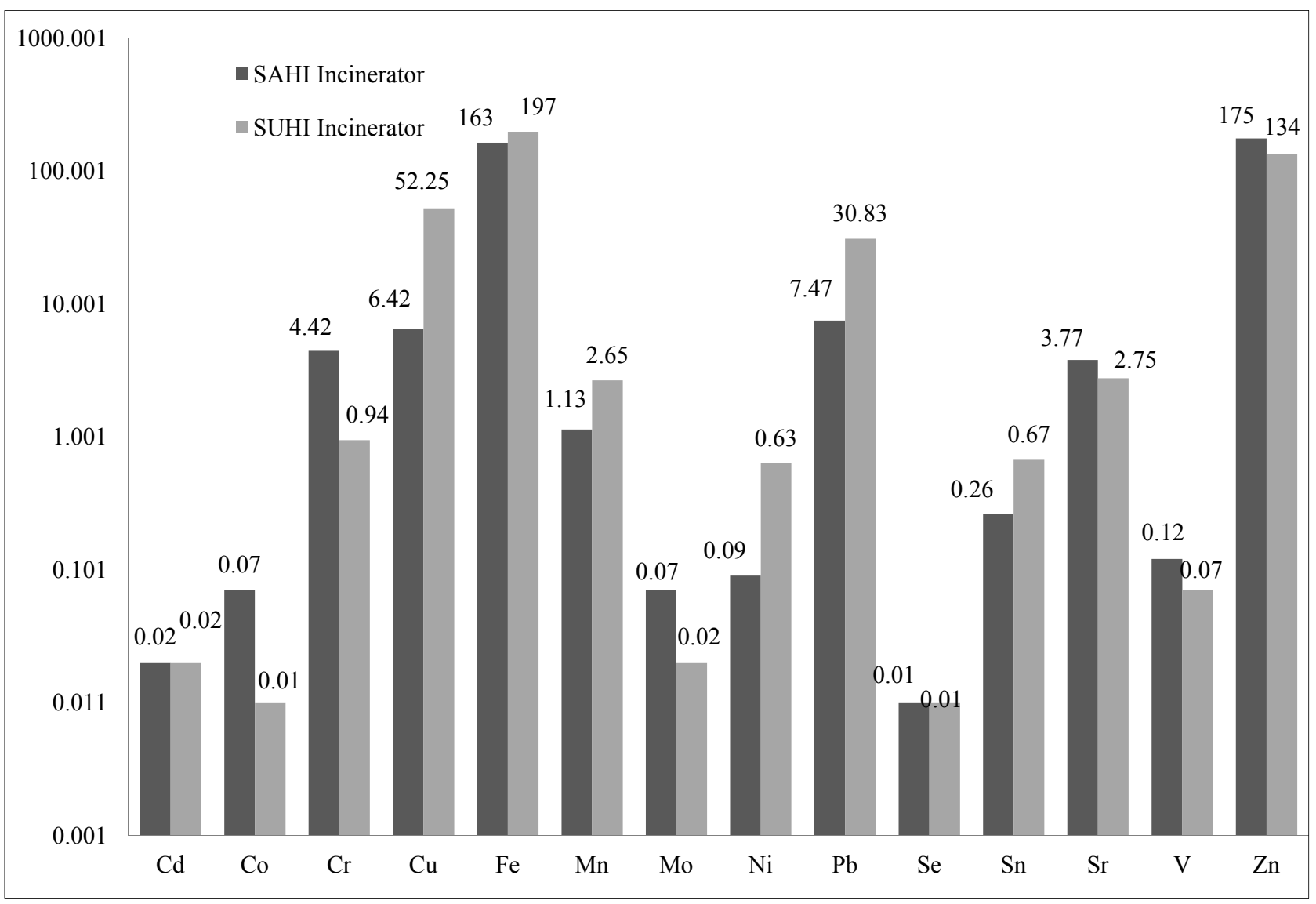

Fig. 2 Average concentration of heavy metals in bottom ash of incinerators.

Table 3 Comparison of parameters of bottom ash of hospital incinerators with published results and EPA TCLP levels.

\begin{tabular}{lllllll}
\hline Heavy metals & SAHI (a) & SUHI (a) & Sabah (b) & Ben-Sina (b) & Psychological (b) $\begin{array}{l}\text { Regulated levels } \\
\text { for toxicity of } \\
\text { heavy metals (c) }\end{array}$ \\
\hline $\mathrm{Cd}$ & $0.01-0.03$ & $0.01-0.02$ & $2.0-10.0$ & $1.0-56.0$ & $2-16$. & 1.0 \\
$\mathrm{Co}$ & $0.06-0.08$ & $<0.01-0.03$ & $\mathrm{NR}$ & $\mathrm{NR}$ & $\mathrm{NR}$ & NR \\
$\mathrm{Cr}$ & $4.58-4.10$ & $0.91-1.07$ & $200-667$ & $100-2,000$ & $183-633$ & 5.0 \\
$\mathrm{Cu}$ & $6.15-7.50$ & $15.6-79.7$ & $150-687$ & $138-1,998$ & $208-2,034$ & NR \\
$\mathrm{Fe}$ & $46.9-191$ & $127-227$ & $727-8,867$ & $1,167-5,700$ & $4,233-1,233$ & NR \\
$\mathrm{Mn}$ & $1.10-1.24$ & $2.10-3.44$ & $127-597$ & $31-328$ & $99-389$ & NR \\
$\mathrm{Mo}$ & $0.06-0.08$ & $0.01-0.05$ & $\mathrm{NR}$ & $\mathrm{NR}$ & $\mathrm{NR}$ & NR \\
$\mathrm{Ni}$ & $0.08-0.12$ & $0.55-0.76$ & $24-41$ & $25-141$ & $21-52$ & 5.0 \\
$\mathrm{~Pb}$ & $7.09-8.58$ & $27.0-35.3$ & $601-2,940$ & $192-5,866$ & $815-2,305$ & 1.0 \\
$\mathrm{Se}$ & $<0.01-0.01$ & $<0.01-0.01$ & $\mathrm{NR}$ & $\mathrm{NR}$ & $\mathrm{NR}$ & $\mathrm{NR}$ \\
$\mathrm{Sn}$ & $0.26-0.27$ & $0.60-0.72$ & $\mathrm{NR}$ & $\mathrm{NR}$ & $\mathrm{NR}$ & $\mathrm{NR}$ \\
$\mathrm{Sr}$ & $3.55-4.20$ & $2.30-3.18$ & $\mathrm{NR}$ & $\mathrm{NR}$ & $\mathrm{NR}$ & $\mathrm{NR}$ \\
$\mathrm{V}$ & $0.10-012$ & $0.06-0.09$ & $\mathrm{NR}$ & $\mathrm{NR}$ & $\mathrm{NR}$ & NR \\
$\mathrm{Zn}$ & $120-194$ & $111-185$ & $730-6,800$ & $827-27,800$ & $-16,067$ & \\
\hline
\end{tabular}

* Note: (a) This study; (b) [3]; and (c) [26]. 
amount in the bottom ashes. When the levels of heavy metal of this study were compared with published data, it was found that the existing incinerators' performances were much better than previously, as shown in Table 3.

It seemed likely that both SAHI and SUHI incinerators had high efficiency to reduce the heavy metals. This means that the incinerator performance depends entirely on the combustion degrees. To classify the produced bottom ash from the two incinerators as hazardous or not, toxicity characteristic leaching procedure and characteristic waste Toxicity Characteristic Leaching Procedure (TCLP) list was applied [26]. According to the TCLP guidelines, results showed that $\mathrm{Cd}, \mathrm{Cr}$ and $\mathrm{Se}$ had a lower concentration than TCLP. But $\mathrm{Pb}$ concentration was found to have exceeded the permissible limits. Due to $\mathrm{Pb}$ toxicity, the bottom ash is considered hazardous waste, as shown in Table 3. Therefore, the produced bottom ash from the two incinerators may be classified as hazardous wastes, and care should be taken during dumping [25, 27, 28]. Otherwise, it can cause problems to the surrounding environment [29, 30]. Therefore, utilization of bottom ash is much safer than dumping it in landfill sites [31-33].

\section{Conclusions}

The results of this study demonstrated that incineration is the best technology to destroy the increasing volume of hospital wastes. Hospital incinerators do not completely destroy heavy metals, but simply concentrate them into bottom ash. Bottom ash residues arising from both incinerators were found to contain high concentrations of hazardous elements, such as $\mathrm{Cd}, \mathrm{Co}, \mathrm{Cr}, \mathrm{Cu}, \mathrm{Fe}, \mathrm{Mn}, \mathrm{Mo}, \mathrm{Ni}, \mathrm{Pb}, \mathrm{Se}, \mathrm{Sn}$, $\mathrm{Sr}, \mathrm{V}$ and $\mathrm{Zn}$. However, the performances of both incinerators were much better than previously. Fe, Zn, $\mathrm{Pb}$ and $\mathrm{Cu}$ were found in the bottom ashes of two hospital incinerators. They were in high concentrations compared to other heavy metals found in the bottom ashes. Moreover, the highest melting points of some heavy metals mean a larger amount of their residues. The average concentrations of $\mathrm{Pb}$ were found to be higher than TCLP; therefore, bottom ashes could be classified as hazardous waste on most sampling days. It is likely to have highly mobile constituents of heavy metals. If they were improperly managed, they could contaminate the groundwater. Therefore, it is recommended that more efforts are needed to identify why bottom ashes contain high concentrations of $\mathrm{Fe}, \mathrm{Zn}, \mathrm{Pb}$ and $\mathrm{Cu}$. Hospital bottom ashes should be disposed by properly designed engineered treatment methods.

\section{Acknowledgements}

The author is grateful to the Kuwait Institute for Scientific Research (KISR) management for the financial support to conduct this project. The author would like to express his warm thanks to Prof. Alan Moghissi for his guidance and good comments on this manuscript. Thanks are also due to Prof. Mohammed Al-Sarawi, manager of Earth Sciences and Environment Department, Kuwait University (KU), for his critical review of the manuscript. Special thanks go to author's laboratory staff who always kept things running and doing analysis on time. The author's wishes to thank the engineers and technical staff from the National Cleaning Company (NCC) for their technical information and support during this study.

\section{References}

[1] Al-Humaidan, S. M. 2006. “Ahmadi Hospital Waste Management and Health care: Workers Perception”. The Proceedings of 4th Euro-Arab Environment Conference and Exhibition. 27-29, November, State of Kuwait, 589-599.

[2] Elliott, P., Shaddick, G., and Kleinschmidt, L. 2000. "Cancer Incidence Adverse near Municipal Waste Incinerators in Great Britain." Br. Journal Cancer 73: 702-710.

[3] Al-Meshan, M., Nasrallah, H., and Ahmed, A. 2001. "Comparative Study of Heavy Metals in Bottom Ash from Hospital Incinerators in the State of Kuwait." Kuwait Journal of Science 28 (2): 347-857. 
[4] Lo, H., and Liao, Y. 2007. "The Metal Leaching and Acid-neutralizing Capacity of Msw. Incinerator Ash Co-disposed with Msw. in Landfill Sites." Journal of Hazardous Materials 142: 512-519.

[5] Gidarakos, E., Petrantonaki, M., Anastasiadou, K., and Schramm, K. 2009. "Characterization and Hazard Evaluation of Bottom Ash Produced from Incinerated Hospital Waste." Journal of Hazardous Materials 172: 935-942.

[6] Shim, Y., Rhee, S., and Lee, W. 2005. "Comparison of Leaching Characteristics of Heavy Metals from Bottom and Fly Ashes in Korea and Japan." Waste Management 25: 473-480.

[7] Alba, N., Gasso, S., Lacorte, T., and Baldasano, H. 1997. "Characterization of Municipal Solid Waste Incineration Residues from Facilities with Different Air Pollution Control System." Waste Management 47: 1170-1179.

[8] Ibanez, R., Andres, A., Viguri, J. R., Ortiz, I., and Ibrabien, J. A. 2000. "Characterization and Management of Incinerator Wastes." Journal of Hazardous Materials 15: 793: 2-5.

[9] Zhao, L., Zhang, F., Wang, W., and Zhu, J. 2009. "Chemical Properties of Heavy Metals in Typical Hospital Waste Incinerator Ashes in China." Waste Management Journal 29 (3): 114-115.

[10] Kougemitrou, I., Godelitsas, A., Tsabaris, C., Stathopoulos, V., and Papandreou, P. 2011. "Characterization and Management of Ash Produced in the Hospital Waste Incinerator of Athens, Greece." Journal of Hazardous Materials 187 (1-3): 421-432.

[11] Zhao, L., Zhang, F., Mengjun, L., Zhen, G. L., and Wu, D. 2010. "Typical Pollutants in Bottom Ashes from a Typical Medical Waste Incinerator." Journal of Hazardous Materials 15 (173): 181-185.

[12] Zakaria, M., labib, O., Mohammed, M., El-Shall, W., and Hussein, A. 2005. "Assessment of Combustion Products of Medical Waste Incinerators in Alexandria." The Journal of the Egyptian Public Health Association 80 (3-4): 407-431.

[13] Levasseur, B., Myriam, C., Jean-Francois, B., and Mercier, G. 2006. "Metals Removal from Municipal Waste Incinerator fly Ashes and Reuse of Treated Leaches." Journal of Environmental Engineering 132 (5): 497-505.

[14] Astar, M. 1985. "Cost Estimating for Hazardous Waste Incineration." Pollution Engineering 1: 20-25.

[15] Tessitors, J., and Frankle, C. 1988. "Incineration of Hospital Infectious Waste." Pollution Engineering Journal 2: 82-88.

[16] Doyle, B. W., Drum, D. A., and Lauber, J. D. 1985. "The Smoldering Question of Hospital Wastes."
Pollution Engineering 1: 35-39.

[17] Timothy, A., Timothy, O., and Morenike, A. Ji. 2013. "Heavy Metals Concentrations Around of a Hospital Incinerator and a Municipal Dumpsite in Ibadan City, South-West Nigeria." Journal of Apply Science and Environment Management 17 (3): 419-422.

[18] Rich, C., and Cherry, K. 1989. "The Liabilities of Hospital Waste Incineration.” Pollution Engineering 1: 48-57.

[19] Shen, T. 1986. "Hazardous Waste Incineration: Emissions and Their Control." Pollution Engineering: 1: 50-53.

[20] Belevir, H., and Moench, H. 2000. "Factors Determining the Element Behavior in Municipal Solid Waste Incinerators." Field studies, Environment Science Technology 34: 2501-2506.

[21] Toledo, J., Corella, J., and Corella, L. 2005. "The Partitioning of Heavy Metals in Incineration of Sludge and Waste in a Bubbling Fluidized Bed, Interpretation of Results with a Conceptual Model." Journal Hazardous material B 126: 158-168.

[22] Varian Co. 2006. "ICP-OES Spectrometers: Varian SPS3, Sample Preparation, System and Diluter, Operation Manual." Varian Australia Pty. Australia.

[23] Water Pollution Control Federation (WPCF). 2005. "Standard Methods for the Examination of Water and Wastewater." Test Methods, Water Pollution Control Federation, Washington, DC: WPCF.

[24] Powell, C. 1987. "Incineration of hospital wastes." Hazardous Waste Management 37 (7): 836-839.

[25] Gautam, V., Thapar, R., and Sharma, M. 2010. "Biomedical waste Management: Incineration vs. Environmental Safety." Indian Journal of Medical Microbiology 28 (3): 131-192.

[26] USEPA (United State Environmental Protection Agency). 2010. "Toxicity Characteristic Leaching Procedure." Fed. Register, 51, 216 and 40642: USEPA.

[27] Nurmesniemi, R., Poykio, K., Manskinen, O. D., and Makela, M. 2012. "Comparison of the Forest Fertilizer of Fly Ash Fractions from the MW Power Plant of a Fluting Board Mill Incinerating Peat and Forest Residues." The 27th International Conference on Solid Waste Technology and Management, March 11-14, Ph. Pa., USA, 706-716.

[28] EC. 2003. Council Decision of 19 December 202 Establishing Criteria and Procedure for the Acceptance of Waste at Landfills. Pursuant to Article 16 of and Annex II to Directive 1999/31/EC.

[29] Al-Muzaini, S., and Jacob, P. 1997. "Trace Metals in the near Shore Sediments of the Shuaiba Industrial Area of Kuwait from August 1993 to June 1994." J. Fac. Sci. U.A.E. 9 (1): 1-10. 

Shuaiba Hospital Incinerators in Kuwait

[30] Al-Muzaini, S., and Jacob, P. 1996. "The Distribution of $\mathrm{V}, \mathrm{Ni}, \mathrm{Cr}, \mathrm{Cd}$ and $\mathrm{Pb}$ in Topsoil of the Shuaiba Industrial Area of Kuwait." Environmental Toxicology and Water Quality Environment International Journal 11: $285-292$.

[31] Orava, H., Nordman, T., and Kuopanportti. H. 2006. "Increase the Utilization of Fly Ash with Electrostatic Precipitation." Mineral Engineering 19 (15):1596-1602.

[32] Pasquini, M., and Alexander, M. 2004. "Chemical Properties of Urban Waste Ash Produced by Open Burning on the Jos Plateau: Implications for Agriculture." Science of the Total Environment 319
(1-3): 225-240.

[33] Zhang, S., Yamasaki, S., and Nanzyo, M. 2002. "Waste Ashes for Use in Agricultural Production I: Lining Effect Content of Plant Nutrients and Chemical Characteristics of Some Metals." Science of the Total Environment 248 (1-3): 215-225.

[34] Al-Sudairawi, M., Saeed, T., Al-Rashidi, M., Yafaoui, H., Al-Shatti, A., Al-Wadi, M., Ahmed, N., Sinan, M., Al-Awadi, L., Rashad, M., and Bahaaeldien, M. 2001. Assess the Impact of Air Pollution Emitted from Medical Waste Incinerators on the Hospital Environment and the Surrounding Areas. Final report. 